\title{
LICURY CAKE IN LAMB FEED: CHARACTERISTICS OF CARCASS AND NON-CARCASS COMPONENTS
}

\author{
Torta de licuri na alimentação de cordeiros: características de \\ carcaça e componentes não-carcaça
}

\author{
Fernanda Maria dos Santos ${ }^{1}$, Juliana Dantas Rodrigues Santos ${ }^{1}$, Francisco Allan Leandro de Carvalho', \\ Mário Adriano Ávila Queiroz², Sandra Mari Yamamoto', Omair Dantas Guimarães ${ }^{1}$
}

\begin{abstract}
The use of alternative foods, such as agroindustrial residues, for animal feeding aims to reduce production costs and increase animal productivity. Therefore, the objective of this study was to evaluate the effect of different levels of licury cake added to the diet of non-standardbred lambs (NSB). The study involved 20 male castrated NSB lambs, with an average age of $120 \pm 5$ days and initial and final average weights of $25 \pm 2 \mathrm{~kg}$ and $34 \pm 2 \mathrm{~kg}$, respectively; the lambs were kept in a feedlot and distributed in a completely random block design for 75 days. Three isonitrogenic diets (17\% protein) with three levels of licury cake supplementation (8, 16 and $24 \%$ ) and a control diet (0\% licury cake) were used. Elephant grass (Pennisetum purpureum) concentrate in a 50:50 ratio and the different levels of licuri cake were provided twice a day. The residue normality and variances compared by orthogonal and polynomial regression contrasts were verified for data analysis at 5\% significance. The licury cake levels did not influence (P $>0.05)$ the dry matter intake, minimum and maximum fat thickness, empty gastrointestinal tract, spleen, heart, kidneys, anterior and posterior quarters, muscle yield, marbling, other tissues or ash. There was a quadratic effect $(\mathrm{P}<0.05)$ for the average daily weight, skin yield and crude protein. Increasing the levels of licury cake reduced $(\mathrm{P}<0.05)$ real yield, loin eye area, and increased $(\mathrm{P}<0.05)$ leg yield, bone and moisture. A diet including up to $13 \%$ licury cake can be indicated as an alternative feeding source for feedlot NSB sheep.
\end{abstract}

Index terms: Centesimal composition; byproduct; liver.

\section{RESUMO}

O uso de alimentos alternativos na dieta animal, como resíduos agroindustriais, tem como propósito reduzir os custos de produção e aumentar a produtividade animal. Nesse contexto, objetivou-se avaliar o efeito da inclusão de diferentes níveis de torta de licuri em dieta de cordeiros sem padrão racial definido (SPRD). Foram confinados 20 cordeiros, machos e castrados, com idade média de $120 \pm 5$ dias, distribuídos em delineamento em blocos inteiramente casualizados, durante 75 dias. Foram utilizadas três dietas isonitrogenadas ( $17 \%$ de proteína), sendo três níveis de inclusão de torta de licuri $(8,16$ e $24 \%)$ e uma ração testemunha $(0 \%)$. Foi fornecido o capim elefante (Pennisetum purpureum) e concentrado na proporção de 50:50 e os diferentes níveis de torta, fornecidas duas vezes ao dia. Para análise dos dados, foi verificada a normalidade dos resíduos e as variâncias comparadas por contrastes ortogonais e regressão polinomial, considerando nível de significância de 5\%. Os níveis de torta de licuri não influenciaram $(\mathrm{P}>0,05)$ o consumo de matéria seca, espessura de gordura mínima e máxima, trato gastrintestinal vazio, baço, coração, rins, quarto dianteiros e traseiros, rendimento de músculo, gordura intermuscular, outros tecidos e cinzas. Houve efeito quadrático $(\mathrm{P}<0,05)$ para ganho de peso médio diário, rendimento de pele e proteína bruta. Níveis crescentes de torta de licuri reduziram $(\mathrm{P}<0,05) \mathrm{o}$ rendimento verdadeiro, área de olho de lombo e aumentaram $(\mathrm{P}<0,05)$ o rendimento de perna, osso e umidade. A torta de licuri pode ser indicada como fonte alimentar alternativa até o nível de $13 \%$ para cordeiros SPRD em confinamento.

Termos para indexação: Composição centesimal; coproduto; fígado.

\section{INTRODUCTION}

Alternative foods, mainly agroindustrial byproducts, can be used for animal feeding without increasing the costs of the production system, especially in low feed availability periods. Licury (Syagrus coronata MattiusBeccari) is one of the most common palm trees of the semi-arid region of Brazil and tolerates long drought periods well.
Licury cake, which is obtained during the processing of the licury palm nut for oil extraction by pressing, contains approximately $23.6 \%$ protein, $10.1 \%$ ethereal extract (EE), $51.5 \%$ neuter detergent fiber (NDF), 34.9\& acid detergent fiber (ADF) and 17.3\% (Borja et al., 2010), and can be utilized as an alternative source of animal feed, reducing feeding cost (Queiroga et al., 2010). According to Correia et al. (2011), in general, oleaginous cakes contain a large amount of protein, are high in cost and include protein fundamental to maintaining the

${ }^{1}$ Universidade Federal do Vale do São Francisco/UNIVASF - Câmpus de Ciências Agrárias - Petrolina - PE - Brasil

²Universidade Federal do Vale do São Francisco/UNIVASF - Câmpus de Ciências Agrárias - BR 407 - Km 12 - Lote 543 - $56310-770$ - Petrolina PE - Brasil - mario.queiroz@univasf.edu.br

Received in december 3, 2014 and approved in march 23, 2015

Ciênc. Agrotec., Lavras, v.39, n.3, p.260-268, maio/jun., 2015 
productive performance of the animals. Moreover, byproducts rich in ethereal extract (EE) can be used to increase the energetic density of the diet or to substitute energy sources that are traditionally utilized in animal nutrition.

Studies involving the evaluation of agroindustrial residues as alternatives in ruminant feeding cannot be restricted to performance results aiming only at cost reduction, but should also show the impact these residues would have on the meat and carcass quality, meeting consumers' growing demand, and on the non-carcass component yield.

Usually only the carcass is considered as the commercial unit, and other parts that are edible or can be utilized in the chemical and/or cosmetic industry are ignored (Silva Sobrinho, 2001), even though they are a way to add value to the product and increase the economic turnover activity.

Therefore, the aim of this study was to evaluate the dry matter intake, weight gain, carcass yield, noncarcass component yield, commercial cut yield, and the loin chemical composition of NSB lambs whose diets had different levels of licury cake.

\section{MATERIAL AND METHODS}

The Experiment was carried out in the Sheep and Goat Sector of the Experimental Farm of the campus of
Agricultural Sciences of the Universidade Federal do Vale do São Francisco. Twenty castrated male non-standardbred (NSB) lambs, with an average age of $120 \pm 5$ days, and an average initial body weight of $25 \pm 2 \mathrm{~kg}$ and an average slaughter body weight of $34 \pm 2 \mathrm{~kg}$, were utilized. The animals were individually kept in covered feedlot pens (1 x $2 \mathrm{~m}$ ) provided with watering and front troughs where feeding was provided twice a day. This study was evaluated and approved by the UNIVASF ethics committee under the registration number 0037/190811.

Before the beginning of the experiment, the animals were weighed, identified and wormed. The lambs were distributed in an entirely random block design according to their initial body weight and received an isonitrogenic diet (17\% crude protein) with four supplementation levels of licury cake $(0,8,16,24 \% \mathrm{DM})$ for 75 days, including 10 days to adapt to the diet and the installations, with water ad libitum.

The provided diets (Table 1) consisted of elephant grass (Pennisetum purpureum), ground in a forage machine and a $50 \%$ concentrate of corn, soybean bran, mineral supplements and different levels of licury cake formulated according to the requirements of the National Research Council (National Research Council-NRC, 2007) for a daily gain of $200 \mathrm{~g}$. The licury cake was obtained in the municipality of Miguel Calmon, BA, as a byproduct of the oil extraction process.

Table 1: Chemical and bromatological composition of the experimental diets.

\begin{tabular}{|c|c|c|c|c|}
\hline \multirow{2}{*}{ Ingredients $(\% \mathrm{MS})$} & \multicolumn{4}{|c|}{ Treatments $(\%)$} \\
\hline & 0 & 8 & 16 & 24 \\
\hline Ground corn & 23.9 & 21.2 & 18.3 & 15.5 \\
\hline Soybean bran & 24.3 & 18.9 & 13.9 & 8.7 \\
\hline Licury cake $^{1}$ & 0 & 8.0 & 16.0 & 24.0 \\
\hline Mineral mixture-Sheep ${ }^{2}$ & 1.9 & 1.9 & 1.9 & 1.9 \\
\hline Elephant grass & 50.0 & 50.0 & 50.0 & 50.0 \\
\hline TOTAL & 100.0 & 100.0 & 100.0 & 100.0 \\
\hline Nutrients\%MS & 0 & 8 & 16 & 24 \\
\hline Mineral matter & 8.2 & 9.0 & 8.6 & 8.1 \\
\hline Crude protein & 17.4 & 17.1 & 17.5 & 17.2 \\
\hline Ether Extract & 2.4 & 4.2 & 4.4 & 5.3 \\
\hline Neutral detergent fiber & 43.5 & 59.32 & 56.34 & 51.7 \\
\hline Non-fibrous carbohydrate (NFC) ${ }^{3}$ & 26.9 & 10.4 & 12.1 & 19.7 \\
\hline Metabolizable energy $(\mathrm{Mcal} / \mathrm{kg})^{4}$ & 2.24 & 2.24 & 2.26 & 2.27 \\
\hline
\end{tabular}


The feed was provided twice a day, ad libitum, and, to assure maximum voluntary intake, a $10 \%$ adjustment was made based on the amount provided the previous day and the daily observed leftovers.

After the feedlot period, during pre-slaughter, the lambs were weighed for non-fasting body weight (NFBW) and then submitted to a solid fast with a hydric diet for 18 hours and weighed again to obtain fasting body weight (FBW) or slaughter body weight. The animals were desensitized by concussion and bled after the jugular vein and carotid artery were severed according to the Regulation of the Industrial and Sanitary Inspection of Animal Products (Regulamento da Inspeção Industrial e Sanitária de Produtos de Origem Animal - RIISPOA) (Brasil, 1997). The desanguination was followed by skinning, evisceration, and removal of the head (sectioned in atlanto-occiptal joint) and limb ends (sectioned in the metacarpal and metatarsal bones).

The gastrointestinal tract was emptied and weighed before and after the procedure to obtain the empty body weight $(\mathrm{EBW}=\mathrm{FBW}-\mathrm{GITC})$ to determine the real yield obtained from the relation between the hot carcass weight and the empty body weight (Sañudo; Sierra, 1986). The following formula was utilized to determine the hot carcass yield (HCY): HCY $=(H C W / F B W) \times 100$ (Silva Sobrinho, 2001), where $\mathrm{HCY}=$ hot carcass yield, $\mathrm{HCW}=$ hot carcass weight, FBW= fasting body weight.

The weight of the organs (skin, spleen, liver, heart and kidneys) was added to determine the non-carcass component. Next, the carcasses were hung by the tarsometatarsal joints on appropriate hooks and posteriorly cut longitudinally to obtain half carcasses, right and left, which were individually weighed. The left half carcass was divided to obtain the commercial cuts of the anterior quarter (neck, shoulder and ribs) and posterior quarter (loin and leg, separately). All the cuts were weighed to calculate their respective yields.

Using a paquimeter, measurements of the loin of each animal were taken in the dorsal portion of the Longissimus lumborum muscle of the $13^{\text {th }}$ thoracic vertebrae to calculate the loin eye area (LEA) according to the formula described by (Silva; Pires, 2000), using four measurements: the maximum and minimum covering fat thicknesses and the maximum $(\mathrm{X})$ and minimum (Y) lengths. The loins were identified, stored in plastic bags and frozen in a freezer at $-18^{\circ} \mathrm{C}$ to make posterior dissection activities easier. After thawing inside the plastic bags, the samples were weighed. Next, the muscle tissues (total dissected muscles after the complete removal of adhered subcutaneous and intermuscular fat), bone tissues (dissected after the total removal of all muscles and adhered subcutaneous and intermuscular fat), subcutaneous fat (external fat located directly under the skin), intramuscular fat (fat under the deep fascia associated to muscles) and other tissues (fascia, tendons, blood vessels) were dissected and individually weighed to be expressed as a percentage in relation to the weight of the respective cut (McCutcheon et al., 1993).

The Longissimus lumborum muscle was separated to determine the centesimal composition. The meat samples were ground in a mini-processor, homogenized, kept in an oven at $55{ }^{\circ} \mathrm{C}$ for 72 hours, and then ground again in a ball mill. Later, analyses were carried out to determine moisture, crude protein (CP), ash (MM) according to Association Of Official Analytical ChemistsAOAC (2007), and ether extract (EE) content in an extractor (ANKOM TX10) following the methodology proposed by AOCS Am 5-04 (2009).

The results were analyzed by the statistical program SAS (Versão 9.1, 2003). The normality of the residues was previously verified by the Shapiro-Wilks' Test (PROC UNIVARIATE), and variances were compared by orthogonal contrasts and polynomial regression (PROC GLM and PROC REG, respectively) at the 5\% significance level.

\section{RESULTS AND DISCUSSION}

The average daily weight gain (ADWG) presented a quadratic effect $(\mathrm{P}<0.05)$ as a function of the increase of licury cake in the diet (Figure 1). According to the regression equation, the greatest $\mathrm{ADWG}(164.22 \mathrm{~g})$ was estimated for lambs fed with a diet including the addition of $10.22 \%$ licury cake.

The increase of the fat content (EE) in the diet due to the inclusion of licury cake at levels higher than $10.22 \%$ may have compromised the animal performance because of the decrease of the ruminal degradation rate of the feed (Gibb et al., 2005). Another factor that may have contributed was reduced acceptability due to the greater amount of fragments of the highly lignified external tegument of the palm nut. The effect of dry matter intake $(\mathrm{P}>0.05)$ was not verified (Table 2$)$, presenting an average of $672.5 \mathrm{~g} / \mathrm{animal} /$ day, lower than the one predicted by the NRC (2007), which describes the intake of 1.0 to $1.3 \mathrm{~kg}$ of dry matter for the animal category utilized in this study. The fact that the evaluated animals are non-standardbred may have contributed to the low intake of dry matter, as well as the low quality of the elephant grass, which had been cut 120 days before data collection, and the neutral detergent fiber (NDF) of $72 \%$ and $200 \mathrm{~g}$ gains per day. 


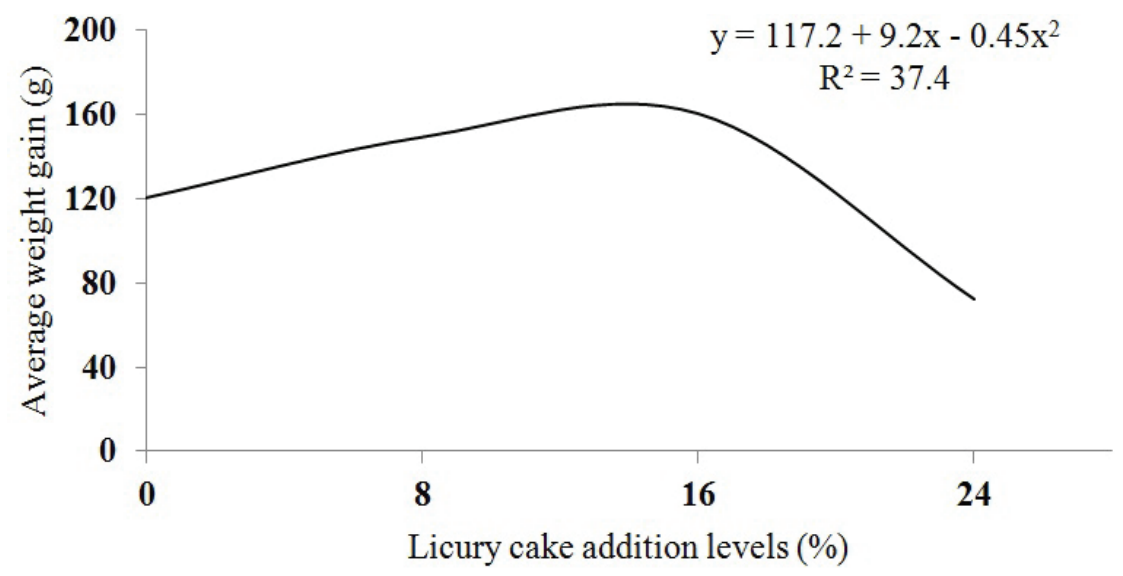

Figure 1: Average daily weight gain (g) of lambs fed with different levels of licury cake.

Table 2: Averages of dry matter intake (DMI), empty body weight (EBW), real yield (RY), loin eye area (LEA) and maximum (MaxFT) and minimum (MinFT) fat thickness of sheep fed with different licury levels.

\begin{tabular}{lrrrrrrr}
\hline \multirow{2}{*}{ Variable } & \multicolumn{9}{c}{ Treatment $^{1}$} & \multirow{2}{*}{ ASE $^{2}$} & \multirow{2}{*}{$\mathrm{R}^{2}$} & RE $^{3}$ \\
\cline { 2 - 4 } & \multicolumn{1}{c}{0} & \multicolumn{1}{c}{16} & \multicolumn{1}{c}{24} & & & \\
\hline DMI $(\mathrm{g})$ & 644.6 & 698.4 & 729.0 & 618.1 & 30.30 & - & $\hat{\mathrm{Y}}=672.5$ \\
EBW $(\mathrm{kg})$ & 33.7 & 32.1 & 31.8 & 30.7 & 0.37 & 42.4 & $\hat{\mathrm{Y}}=33.5-0.12 \mathrm{x}$ \\
RY $(\%)$ & 53.1 & 53.2 & 44.9 & 43.7 & 2.00 & 21.9 & $\hat{\mathrm{Y}}=54.18-0.455 \mathrm{x}$ \\
LEA $\left(\mathrm{cm}^{2}\right)$ & 12.5 & 11.5 & 10.6 & 8.3 & 0.70 & 25.7 & $\hat{\mathrm{Y}}=12.75-0.16 \mathrm{x}$ \\
MinFT $(\mathrm{mm})$ & 1.7 & 1.1 & 1.6 & 1.0 & 0.14 & - & $\hat{\mathrm{Y}}=1.37$ \\
MaxFT $(\mathrm{mm})$ & 5.8 & 4.7 & 5.6 & 5.4 & 0.27 & - & $\hat{\mathrm{Y}}=5.36$ \\
\hline
\end{tabular}

${ }^{1}$ Treatment: $0=$ without licury cake in total diet, $8 \%$ licury cake in $\%$ DM of total diet, $16 \%$ licury cake in $\%$ DM of total diet, $24 \%$ licury cake in $\% \mathrm{DM}$ of total diet, ${ }^{2} \mathrm{ASE}=$ Average standard error. $\mathrm{R}^{2}=$ Coefficient of determination; $\mathrm{RE}^{3}=$ Regression equation .

Regarding the decrease verified for the empty body weight $(\mathrm{EBW})$, real yield $(\mathrm{RY})$ and loin eye area (LEA) of the animals, a reduction of $9.8,17.7$ and $33.6 \%$, respectively, was observed. For every $8 \%$ inclusion, there was an estimated decrease of $0.96 \mathrm{~kg}$ in EBW and consequent $3.64 \%$ of RY that consists of the relationship between the hot carcass weight and EBW. However, Xenofonte et al. (2009) evaluating the addition of babaçu bran to sheep's diets, did not observe varying effects among the treatments $(0,10,20$ and $30 \%$ addition), with an average of $56.07 \%$ for RY.

The LEA measurement done in the Longissimus muscle shows that it is directly related to the total carcass muscles. In this study, there was an LEA decrease of approximately $1.28 \mathrm{~cm}^{2}$ for every $8 \%$ of added licury cake, confirming the same behavior for RY. The addition of licury cake negatively influenced ECW and HCW (half carcass height), and LEA, consequently. Highly fermentable carbohydrates such as starch are important energy sources in ruminant feedlot systems because they foster carcass accumulation (Queiroz et al., 2008; Ítavo et al., 2014). Substituting corn for licury cake may have reduced this nutrient in the diet and, therefore, reduced LEA. The late development of the Longissimus lumborum muscle can also explain the reduction of its yield. Similar results were observed by Rodrigues et al. (2013) when evaluating increasing levels of sunflower cake $(0,7,14$, 21 and $28 \%$ ) in sheep's diets; the yields decreased as the cake levels increased.

The other variables, minimum fat thickness (MinFT) and maximum fat thickness (MaxFT), were not influenced by licury cake addition and presented 
averages of 1.37 and $5.36 \mathrm{~mm}$ for minimum and maximum fat thickness, respectively. Fat gives nutritional value, tenderness, flavor, succulence and protection to the meat during chilling; however, when in excess, it has a negative impact on consumer preference. The addition of licury cake did not change the fat thickness in the Longissimus. Xenofonte et al. (2009) observed that the minimum fat thickness was not affected by the additional levels of babaçu bran in the diet, but on average the fat was 0.28 mm thick, smaller than the thickness found in this study. This can be related to the slaughter body weight and the ether extract content of the diets.

According to Osório et al. (2002), to enhance the animal's total quality, not only the carcass or live weight but also the "fifth quarter" (the non-carcass components) should be considered. The increase of licury cake in the diet was associated with a linear reduction $(\mathrm{P}<0.01)$ of the blood yield (Table 3 ); each additional $8 \%$ of licury cake resulted in a decrease of $0.24 \%$ for the blood yield. The animals fed without licury cake displayed better growth, and higher half carcass weight (HCW), which resulted in higher slaughter weights and, therefore, higher blood supply. In some regions, blood is utilized in cooking as a way to add value to the product. For example, to make pork sausages and other gastronomic delicacies, blood is the ingredient used in a greater amount due to its low cost.

Regarding skin yield, the verified quadratic effect $(\mathrm{P}<0.05)$ was similar to ADWG. The maximum value for skin yield (10.72\%) occurred when the level of added licury cake was $13 \%$. This value is higher than those found by Homem Júnior et al. (2010) who obtained an average of $6.49 \%$ value for skin yield in an evaluation of lambs fed with sunflower grains or protected fat. The skin is the most important and valued organ because it commands the highest price, which ranges from 10 to $20 \%$ of the total animal value (Tonetto et al. 2004).

The gastrointestinal tract content is one of the noncarcass components that contributes the highest percentage to sheep body weight. The increase of licury cake in the diet does not make a difference $(\mathrm{P}>0.05)$ in the EGT yield $(10.68 \%)$. There was no observed effect $(\mathrm{P}>0.05)$ for the yield of spleen, heart and kidneys, which presented averages of $0.17,0.46$ and $0.28 \%$, respectively. According to Peron et al. (1993), regardless of the feeding level, the weights of the heart and lungs are not influenced, which indicates that these organs keep their integrity and have priority on nutrient utilization.

However, for every additional $8 \%$ of licury cake, there was a decrease of $0.08 \%$ in the liver yield. Pompeu et al. (2013), evaluating the use of tiffton- 85 hay instead of castor bean peel, observed a reduction of $0.07 \%$ in liver weight for every $33 \%$ of substitution. During an animal lifetime, the organs and viscera have different comparative growth rates, which can be related to the chemical composition of the feed, mainly the energy content (Louvandini et al., 2007); this corroborates the effect of growing EE content on the non-carcass components, such as the liver and skin, observed in this study as a result of adding licury cake to the diet.

Every additional $8 \%$ of licury cake linearly reduced $(\mathrm{P}<0.05)$ the half carcass weight $(\mathrm{HCW})$ by $0.8 \mathrm{~kg}$ (Table 4). High levels of fiber in the diet caused lower digestion and nutrition absorption (Macedo Júnior et al., 2007), and, consequently, lower nutrient intake and carcass weight.

Table 3: Characteristics of non-carcass components of non-standardbred lambs fed with different levels of licury cake.

\begin{tabular}{|c|c|c|c|c|c|c|c|}
\hline \multirow{2}{*}{ Variable $^{1}(\%)$} & \multicolumn{4}{|c|}{ Treatment $^{2}$} & \multirow{2}{*}{$\mathrm{ASE}^{3}$} & \multirow{2}{*}{$\mathrm{R}^{2}$} & \multirow{2}{*}{$\mathrm{RE}^{4}$} \\
\hline & 0 & 8 & 16 & 24 & & & \\
\hline Blood & 3.86 & 3.83 & 3.58 & 3.10 & 0.12 & 30.15 & $\hat{Y}=3.97-0.03 x$ \\
\hline Skin & 8.7 & 10.2 & 9.5 & 7.7 & 0.41 & 27.74 & $\begin{array}{c}\hat{\mathrm{Y}}=8.78+0.26 \mathrm{x}- \\
0.01 \mathrm{x}^{2}\end{array}$ \\
\hline EGT & 10.7 & 11.7 & 9.7 & 10.5 & 0.54 & - & $\hat{\mathrm{Y}}=10.68$ \\
\hline Spleen & 0.2 & 0.8 & 0.2 & 0.2 & 0.01 & - & $\hat{\mathrm{Y}}=0.17$ \\
\hline Liver & 1.7 & 1.8 & 1.5 & 1.4 & 0.05 & 70.62 & $\hat{\mathrm{Y}}=1.87-0.01 \mathrm{x}$ \\
\hline Heart & 0.5 & 0.5 & 0.4 & 0.5 & 0.01 & - & $\hat{\mathrm{Y}}=0.46$ \\
\hline Kidneys & 0.30 & 0.29 & 0.25 & 0.27 & 0.01 & - & $\hat{\mathrm{Y}}=0.28$ \\
\hline
\end{tabular}

${ }^{1}$ EGT $=$ empty gastrointestinal tract; ${ }^{2}$ Treatment: $0=$ without licury cake in total diet, $8 \%$ licury cake in $\%$ DM of total diet, $16 \%$ licury cake in $\% \mathrm{DM}$ of total diet, $24 \%$ licury cake in $\% \mathrm{DM}$ of total diet, ${ }^{2} \mathrm{ASE}=$ Average standard error. $\mathrm{R}^{2}=$ Coefficient of determination; $\mathrm{RE}^{3}=$ Regression equation. 
Although a decrease of $\mathrm{HCW}$ was observed, there was no difference $(\mathrm{P}>0.05)$ in $\mathrm{AQ}$ and $\mathrm{PQ}$ yield, indicating proportional reduction between the parts and, therefore, there was no effect of the licury cake on the yield of these cuts. The results related to leg cut yield presented a linear increase in response $(\mathrm{P}<0.05)$ and growth estimates of $1.44 \%$ for every $8 \%$ addition of licury cake, ranging from $28.5 \%$ to $32.6 \%$ for additions of 0 and 24\%, respectively. According to Silva Sobrinho, Machado and Gastaldi (2002), among the meat cuts, the leg has greater muscularity and is the prime cut of lamb. The late development of the Longissimus lumborum muscle justifies its lower yield when compared to the leg.

In this study, for every $8 \%$ addition of licury cake, there was an increase of $1.44 \%$ for the leg yield and a decrease of $0.96 \%$ for the loin yield. Carvalho et al. (2014) evaluated the effect of diets with different soybean dreg contents on Texel lambs and observed the quadratic effect for the leg yield with the maximum value at $5.33 \%$ addition of soybean dregs to the diet, which corresponds to a leg proportion of $37.16 \%$. Again, the late development of the Longissimus lumborum muscle explains its lower yield when compared to the leg.

Similar to the real yield, the loin weight was reduced $(\mathrm{P}<0.05)$ with the inclusion of licury cake in the diet (Table 5), presenting a decrease of 95.76 $\mathrm{g}$ among the levels tested. However, the loin weight reduction could have occurred because of the inherent digestive characteristics of the feed, which had a higher fiber content in the treatments with licury cake (Table 1).

Although the loin weight of animals that were not fed with licury cake was higher, the muscle proportion did not differ $(\mathrm{P}>0.05)$ and presented an average of $46.06 \%$. Bones constituted most of the non-edible carcass parts. In this study, the loin bone percentage was influenced $(\mathrm{P}<0.05)$ by the level of licury cake added to the diet; thus, with an increasing linear effect the estimated growth for every additional $8 \%$ of licury cake was $1.52 \%$, which allowed a $20.12 \%$ variation between the levels of 0 and $24 \%$ of licury cake. Paim et al. (2014) verified a negative effect of the addition of $19.5 \%$ of cotton bran to lambs' diet on bone formation and development.

The subcutaneous fat decreased $(\mathrm{P}<0.05)$ according to the level of licury cake added to the diet, and the yields were $22.4 \%$ and $17.7 \%$ for the treatments with 0 and $24 \%$ of licury cake, respectively. This affected the commercial value of the carcass because it is a component with greater variability and can depreciate the value of the carcass when in excess, while it positively correlates with the total amount of accumulated fat in the animal body and contributes positively by protecting the carcass from dehydration and meat darkening (Caparra et al., 2007). There was no significant difference in the intramuscular fat of lambs' loin ( $\mathrm{P}>0.05)$, with an average of $6.67 \%$.

In addition to the tissues of the muscles, fat and bones, other tissues that are part of the muscular structure (tendons, arteries, nerves, etc.) should be taken into consideration as elements that can influence the quality and yield of the cut. In this study, it was observed that the licury cake supplementation did not influence $(\mathrm{P}>0.05)$ these parameters. According to Mendonça et al. (2003), there is a reference in the literature to the yield of other tissues in lambs, and the values ranging between 8 to $10 \%$ corroborate the results found in this study $(9.61 \%)$.

Table 4: Averages of half carcass weight (HCW), anterior quarter (AQ), posterior quarter (PQ), leg and loin of sheep fed with different levels of licury cake.

\begin{tabular}{lccccccc}
\hline \multirow{2}{*}{ Variable } & \multicolumn{9}{c}{ Treatment $^{1}$} & \multirow{2}{*}{ ASE $^{2}$} & \multirow{2}{*}{ R $^{2}$} & RE $^{3}$ \\
\cline { 2 - 4 } & \multicolumn{1}{c}{0} & 8 & 16 & 24 & & & \\
\hline PMC (kg) & 8.8 & 8.5 & 7.0 & 6.5 & 0.34 & 7.70 & $\hat{\mathrm{Y}}=8.94-0.10 \mathrm{x}$ \\
QD (\%) & 54.5 & 54.9 & 54.0 & 53.0 & 0.27 & - & $\hat{\mathrm{Y}}=54.10$ \\
QT (\%) & 45.5 & 45.1 & 46.0 & 47.0 & 0.27 & - & $\hat{\mathrm{Y}}=45.90$ \\
Perna (\%) & 28.5 & 28.7 & 31.2 & 32.6 & 0.48 & 30.25 & $\hat{\mathrm{Y}}=28.02+0.18 \mathrm{x}$ \\
Limbo (\%) & 17.0 & 16.8 & 14.9 & 14.4 & 0.32 & 15.65 & $\hat{\mathrm{Y}}=17.06-0.12 \mathrm{x}$ \\
\hline
\end{tabular}

${ }^{1}$ Treatment: $0=$ without licury cake in total diet, $8 \%$ licury cake in $\%$ DM of total diet, $16 \%$ licury cake in $\%$ DM of total diet, $24 \%$ licury cake in $\% \mathrm{DM}$ of total diet, ${ }^{2} \mathrm{ASE}=$ Average standard error. $\mathrm{R}^{2}=$ Coefficient of determination; $\mathrm{RE}^{3}=$ Regression equation . 
Table 5: Loin tissue and centesimal composition of lamb fed with different levels of licury cake.

\begin{tabular}{lrrrrrrc}
\hline \multirow{2}{*}{ Variable $^{1}$} & \multicolumn{9}{c}{ Treatment $^{2}$} & \multirow{2}{*}{ ASE $^{3}$} & \multirow{2}{*}{$\mathrm{R}^{2}$} & RE $^{4}$ \\
\cline { 2 - 4 } & \multicolumn{1}{c}{8} & \multicolumn{1}{c}{16} & \multicolumn{1}{c}{24} & & & \\
\hline Loin weight (g) & 844.0 & 771.9 & 625.6 & 592.2 & 39.40 & 36.3 & $\hat{\mathrm{Y}}=847.41-11.97 \mathrm{x}$ \\
Muscle (\%) & 44.0 & 44.7 & 49.5 & 46.0 & 1.11 & - & $\hat{\mathrm{Y}}=46.06$ \\
Bone (\%) & 16.9 & 16.8 & 21.7 & 20.3 & 0.81 & 35.7 & $\hat{\mathrm{Y}}=16.70+0.19 \mathrm{x}$ \\
Sub. Fat (\%) & 22.4 & 20.7 & 13.9 & 17.7 & 1.11 & 44.31 & $\hat{\mathrm{Y}}=21.93-0.28 \mathrm{x}$ \\
Inter. Fat (\%) & 8.1 & 6.7 & 4.9 & 6.8 & 0.63 & - & $\hat{\mathrm{Y}}=6.67$ \\
Others (\%) & 8.5 & 11.0 & 9.9 & 9.1 & 0.70 & - & $\hat{\mathrm{Y}}=9.61$ \\
Moisture (\%) & 72.81 & 73.76 & 74.33 & 74.76 & 0.23 & 53.00 & $\hat{\mathrm{Y}}=72.95+0.08 \mathrm{x}$ \\
CP (\%) & 22.43 & 22.55 & 22.86 & 21.50 & 0.18 & 39.43 & $\hat{\mathrm{Y}}=22.35+0.09 \mathrm{x}-0.004 \mathrm{x}^{2}$ \\
EE (\%) & 3.93 & 3.07 & 2.33 & 2.64 & 0.21 & 43.75 & $\hat{\mathrm{Y}}=3.98-0.16 \mathrm{x}$ \\
Ashes (\%) & 1.10 & 1.11 & 1.14 & 1.10 & 0.01 & - & $\hat{\mathrm{Y}}=1.12$ \\
\hline
\end{tabular}

${ }^{1}$ Sub. Fat = Subcutaneous fat; Inter. Fat $=$ Intermuscular fat; ${ }^{2}$ Treatment: $0=$ without licury cake in total diet, $8 \%$ licury cake in $\%$ $\mathrm{DM}$ of total diet, $16 \%$ licury cake in $\% \mathrm{DM}$ of total diet, $24 \%$ licury cake in $\% \mathrm{DM}$ of total diet, ${ }^{2} \mathrm{ASE}=$ Average standard error. $\mathrm{R}^{2}=$ Coefficient of determination; $\mathrm{RE}^{3}=$ Regression equation.

Determining the water content is one of the most important factors for food analysis of meat because it is related to meat composition, stability and quality; it may also affect the storage, packaging and processing (Cecchi, 2003). Moreover, the water content influences the carcass yield because the water loss in the carcass during chilling results in weight loss and alters the sensory characteristics of the meat. In this study, an increase $(\mathrm{P}<0.05)$ of the moisture content of the Longissimus lumborum muscle was observed, estimating an increase of $0.64 \%$ for every additional $8 \%$ and a variation of $2.68 \%$ between the treatments with 0 and $24 \%$ of licury cake, whereas the EE content decreased $(\mathrm{P}<0.05)$, showing a reduction of $1.28 \%$. Resende et al. (2008) stated that these two parameters behave inversely, corroborating what happened in the experiment in which the levels of licury cake increased while the ether extract content decreased and the moisture content increased.

Madruga et al. (2008) did not observe an effect from the increasing levels of whole cottonseed on the moist and ether extract contents in the meat of lambs and found averages of $72.79 \%$ and $3.65 \%$, respectively. Santos et al. (2009), when evaluating the average chemical composition of the loin carcass muscles of Santa Inês lambs fed with canola cake, observed that the diet influenced this variable and obtained superior results $(8.29 \%)$ for the ether extract of the meat. The content increase of this variable can be due to the mentioned diet because it presents a higher EE content (5.85\%). According to Zapata et al. (2001), in the
Brazilian northeast, lamb meat presents fat contents that vary from 2.01 to $2.39 \%$, making this supplementation level satisfactory.

Meat is a source of protein from muscles, conjunctive tissues, myofibrils and sarcoplasm (Vaz et al. 2002). There was quadratic effect $(P<0.05)$ for the crude protein contents of the lamb meat, and the highest value $(22.86 \%)$ was observed for lambs fed with a diet including $11.25 \%$ addition of licury cake, according to the equation $\hat{Y}=22.35+0.09 x-0.004 x^{2}$. This behavior was similar to ADWG, but the highest value was for the $10.22 \%$ addition. However, there was no influence $(\mathrm{P}>0.05)$ on the ash content, an average of $1.12 \%$, which was similar to the values mentioned by Prata (1999) for lamb meat (1.1\%).

\section{CONCLUSIONS}

Licury cake can be indicated as an alternative feed source in the diets of confined NSB lambs and when added up to $13 \%$, it results in higher crude protein content and the decrease of fats in the lamb meat. The characteristics of the carcass and non-carcass components of lambs are negatively influenced if the addition level of licury cake is higher than $13 \%$.

\section{REFERENCES}

AOAC (ASSOCIATION OF OFFICIAL ANALYTICAL CHEMISTS). Official methods of analysis. 18.ed.

Washington: AOAC, 2007. 3000 p. 
AOCS. Official Method Am 5-04 - Rapid determination of oil/fat utilizing high temperature solvent extraction. Additions and revisions to the official methods and recommended pratices of the AOCS. 2009.

BORJA, M. S. et al. Effects of feeding licury (Syagrus coronate) cake to growing goats. Asian - Australasian Journal of Animal Science. 23(11):1436-1444, 2010.

BRASIL. Ministério da Agricultura, Pecuária e Abastecimento. Regulamento da inspeção industrial e sanitária de produtos de origem animal - RISPOA. Brasília, 2007. 133 p.

CAPARRA, P. et al. Solar-dried citrus pulp as na alternative energy source in Lamb diets: effects on growth an carcass and meat quality. Small Ruminant Research. 40(3):301-311, 2007.

CARVALHO, S. et. al. Características produtivas de cordeiros terminados em confinamento com dietas contendo diferentes teores de borra de soja. Arquivo Brasileiro de Medicina Veterinária e Zootecnia. 66(1):259-267, 2014.

CECCHI, H. M. Fundamentos teóricos e práticos em análise de alimentos. $2^{\mathrm{a}} \mathrm{ed}$. rev. Campinas, Editora da Unicamp, 2003. 207 p.

CORREIA, B.R. et al. Consumo, digestibilidade e $\mathrm{pH}$ ruminal de novilhos submetidos a dietas com tortas oriundas da produção do biodiesel em substituição ao farelo de soja. Arquivo Brasileiro de Medicina Veterinária e Zootecnia. 63(2):356$363,2011$.

GIBB, D.J. Effect of full-fat hemp seed on performance and tissue fatty acids of feedlot cattle. Canadian Journal of Animal Science. 8(2):223-230, 2005.

HOMEM JÚNIOR, A. C. et al. Grãos de girassol ou gordura protegida em dietas com alto concentrado e ganho compensatório de cordeiros em confinamento. Revista Brasileira de Zootecnia. 39(3):563-571, 2010.

ÍTAVO, L.C.V. et al. Fontes de amido no concentrado de bovinos superprecoces de diferentes classes sexuais. Arquivo Brasileiro Medicina Veterinária e Zootecnia. 66(4):1229-1238, 2014.
LOUVANDINI, H. et al. Desempenho, características de carcaça e constituintes corporais de ovinos Santa Inês alimentados com farelo de girassol em substituição ao farelo de soja na dieta. Revista Brasileira de Zootecnia. 36(3):603-609, 2007.

MACEDO JÚNIOR, G. L. et al. Qualidade da fibra para a dieta de ruminantes. Ciência Animal. 17(1):7-18, 2007.

MADRUGA, M. S. et al. Efeito de dietas com níveis crescentes de caroço de algodão integral sobre a composição química e o perfil de ácidos graxos da carne de cordeiros Santa Inês. Revista Brasileira de Zootecnia. 37(8):1496-1502, 2008.

McCUTCHEON, S.N.; BLAIR, H.T.; PURCHAS, R.W. Body composion and organ weights in fleece weight selected and control Romney rams. New Zealand Journal of Agricultural Research. 36(4):445449, 1993.

MENDONÇA, G.J.C. et al. Morfologia, características da carcaça e componentes do peso vivo em borregos Corriedale e Ideal. Ciência Rural. 33(2):351-355, 2003.

NATIONAL RESEARCH COUNCIL - NRC. Nutrient requirements of small ruminants. Washington, D.C.: National Academy Press, 2007. 362 p.

OSORIO, J. C. S. et al. Produção de carne em cordeiros cruza Border Leicester com ovelhas Corriedale e Ideal.

Revista Brasileira de Zootecnia. 31(3):1469- 1480, 2002.

PAIM, T.P. et al. Carcass traits and fatty acid profile of meat from lambs fedd ifferent cotton seed by-products. Small Ruminant Research. 116(2-3):71-77, 2014.

PERON, J.A. et al. Tamanho dos órgãos internos e distribuição da gordura corporal em novilhos de cinco grupos genéticos, submetidos à alimentação restrita e "ad libitum". Revista Brasileira de Zootecnia. 22(5):813-819, 1993.

POMPEU, R.C.F.F. et al. Características da carcaça e dos componentes não-carcaça de ovinos alimentados com dietas contendo casca de mamona. Revista Brasileira de Saúde e Produção Animal. 14(3):490507, 2013. 
PRATA, L.F. Higiene e inspeção de carnes, pescado e derivados. Jaboticabal: FUNEP, 1999. 217 p.

QUEIROGA, R. C. R. E. et al. Produção e composição química do leite de cabras mestiças Moxotó sob suplementação com óleo de licuri ou de mamona.

Revista Brasileira de Zootecnia. 39(1):204-208, 2010.

QUEIROZ, M. A. A. et al. Desempenho de cordeiros e estimativa da digestibilidade do amido de dietas com diferentes fontes proteicas. Pesquisa Agropecuária Brasileira. 43:1193-1200, 2008.

RESENDE, K. T. et al. Avaliação das exigências de pequenos ruminantes pelos sistemas de alimentação recentemente publicados. Revista Brasileira de Zootecnica. 37(supl.):161-177, 2008.

RIISPOA. Regulamento da Inspeção Industrial e Sanitária de Produtos de Origem Animal. BrasíliaDF: Ministério da Agricultura, 1997. 35 p.

RODRIGUES, D. N. et al. Desempenho de cordeiros confinados, alimentados com dietas à base de torta de girassol. Pesquisa Agropecuária Brasileira. 48(4):426432, 2013.

SANTOS, V. C. et al. Características de carcaça de cordeiros alimentados com grãos e subprodutos da canola. Acta Scientiarum. Animal Science. 31(4):389395, 2009.

SAÑUDO, C.; SIERRA, I. Calidad de la canal en la especie ovina. Ovino. 1:27-153, 1986.
SAS INSTITUTE. SAS/STAT: guide for personal computer; version 9.1. Cary, p. 235, 2003.

SILVA SOBRINHO, A. G. Criação de ovinos. Jaboticabal: Funep, 2001. 302 p.

SILVA SOBRINHO, A.G. et al. Efeito da relação volumoso:concentrado e do peso ao abate sobre os componentes da perna de cordeiros Ile de France $x$ Ideal confinados. Revista Brasileira de Zootecnia. 31(2):1017-1023, 2002.

SILVA, L.F.; PIRES, C.C. Avaliações quantitativas e predição das proporções de osso músculo e gordura da carcaça de ovinos. Revista Brasileira de Zootecnia. 29(4):1253-1260, 2000.

TONETTO, C.J. et al. Rendimentos de cortes da carcaça, características da carne e componentes do peso vivo em cordeiros terminados em três sistemas de alimentação.

Revista Brasileira de Zootecnia. 33(1):234-241, 2004.

VAZ, F. N. et al. Características da carcaça e da carne de novilhos e de vacas de descarte Hereford, terminados em confinamento. Revista Brasileira de Zootecnia. 31(3):1501-1510, 2002.

XENOFONTE, A.R.B. et al. Características de carcaça de ovinos em crescimento alimentados com rações contendo farelo de babaçu. Revista Brasileira de Zootecnia. 38(2):392-398, 2009.

ZAPATA, J. F. F. et al. Características de carcaças de pequenos ruminantes do nordeste do Brasil. Ciência Animal. 11(2):79-86, 2001. 